\title{
Composition and Antimicrobial Activity of the Essential Oil from Aloysia sellowii
}

\author{
Euclésio Simionatto, Carla Porto, Ubiratan F. da Silva, Adriana M. C. Squizani, \\ Ionara I. Dalcol and Ademir F. Morel*
}

\author{
Departamento de Química, NPPN, Universidade Federal de Santa Maria, 97045-100 Santa Maria-RS, Brazil
}

\begin{abstract}
Os óleos essenciais obtidos das partes aéreas de Aloysia sellowii, coletadas em duas diferentes localidades (A e B) do sul do Brasil, foram analisadas por CG, CG-EM, e através de cromatografia gasosa com fases quirais (CGC). Dos quarenta e oito componentes identificados, representando cerca de 93 e $91 \%$ dos óleos das regiões A e B, respectivamente, 1,8-cineol, $\beta$-pineno, sabineno e $\beta$ - $(Z)$-santalol foram os principais componentes. Um "screening" preliminar das duas amostras de óleos de A. sellowii mostrou atividade frente a Artemia salina (LC50 =2,85 $\mu \mathrm{g} \mathrm{mL}^{-1}$ ), além de exibirem atividade antimicrobiana frente a bactérias Gram-positivas e Gram-negativas e frente a leveduras (MIC 1,7-16 $\mathrm{mg} \mathrm{mL}^{-1}$ ).
\end{abstract}

The essential oils obtained from aerial parts of Aloysia sellowii from two different collection locations Southern Brazil (A and B), were analyzed by GC, GC/MS, and chiral phase gas chromatography (CPGC). It was identified 48 compounds representing $\mathrm{ca} 93 \%$ and $91 \%$ of the oils of samples $\mathrm{A}$ and $\mathrm{B}$, respectively. Besides them 1,8-Cineole, $\beta$-pinene, sabinene, and $\beta$-(Z)-santalol were the major components. In a preliminary biological screening the samples of essential oils of $A$. sellowii displayed strong activity in the brine shrimp lethality assay $\left(\mathrm{LC} 50=2.85 \mu \mathrm{g} \mathrm{mL}^{-1}\right.$ ) as well as antimicrobial activity against Gram-positive and Gram-negative microorganisms and two yeasts (MIC 1.7-16 $\mathrm{mg} \mathrm{mL}^{-1}$ ).

Keywords: Aloysia sellowii, essential oil, enantiomeric composition, chiral phase Gas Chromatography

\section{Introduction}

Aloysia (Verbenaceae) is a genus that comprises about 30 species widespread all over the Americas, mainly in the South and Central America countries. ${ }^{1}$ Aloysia sellowii (Briq.) Moldenke [= Lippia affinis (Briq.)], ${ }^{2}$ known as "garupá", "cidrozinho" or "erva de sepultura" is a large aromatic shrub up to 2-4 meters in height, found throughout the greater part of Southern of Brazil (Rio Grande do Sul), Uruguay, Paraguay and Argentina. ${ }^{3,4}$ In Rio Grande do Sul aerial part of this plant is traditionally used by local people as diuretic, stomach ache agent and as a remedy for colds, influenza, and for the treatment of respiratory disorders. ${ }^{3,4}$ There are few studies published about the chemical composition of the essential oils of this genus in spite of their interesting aromas. A. gratissima ${ }^{5}$ and A. triphylla ${ }^{2,6}$ are the most widely studies species.

In our continuing research on the essential oils of Rio Grande do Sul aromatic plants, ${ }^{7,8}$ we have investigated the

*e-mail: afmorel@base.ufsm.br chemical composition of the essential oil of A. sellowii, its antimicrobial activity and the biological screening by brine shrimp lethality assay, which is considered an efficient tool for preliminary evaluation of the pharmacological activity. ${ }^{9}$ In addition, we report on the enantiomeric distributions of the chiral monoterpene constituents in $A$. sellowii.

\section{Results and Discussion}

The leaf oils of $A$. sellowi were obtained by hydrodistillation in 1.2-1.4\% yield. Its constituents were identified by GC-MS using an electron-impact ionization technique and by co-chromatography with authentic samples. Twenty-eight compounds, making up $92.75 \%$ of the oil from Sample A (Santa Maria), and thirty-four compounds, making up $91.04 \%$ of the oil from Sample B (Livramento), were identified. Both oils displayed some qualitative and quantitative differences (see Table 1). The major constituent of the sample A was 1,8-cineole (43.30 $\%$ ), which is present in only $1.16 \%$ in sample B. The oil 
Table 1. Percentage composition of the essential oils of Aloysia sellowii

\begin{tabular}{|c|c|c|c|c|c|c|}
\hline \multicolumn{2}{|c|}{ Compound $^{\mathrm{a}}$} & \multicolumn{2}{|c|}{$\%$ in samples } & \multicolumn{2}{|c|}{ Kovats Indices } & \multirow[t]{2}{*}{ Identification $^{\mathrm{d}}$} \\
\hline & & A & $\mathrm{B}$ & Apolar ${ }^{b}$ & Polar $^{\mathrm{c}}$ & \\
\hline 01 & $\alpha$-Thujene & 0.26 & 0.35 & 931 & 1007 & RI, GC-MS, Co \\
\hline 02 & $\alpha$-Pinene & 5.18 & 1.87 & 939 & 1016 & RI, GC-MS, Co \\
\hline 03 & Camphene & 0.33 & - & 953 & 1060 & RI, GC-MS \\
\hline 04 & $\beta$-Pinene & 12.60 & 14.58 & 980 & 1114 & RI, GC-MS, Co \\
\hline 05 & Sabinene & - & 12.62 & 976 & 1065 & RI, GC-MS, Co \\
\hline 06 & Myrcene & 1.31 & 2.32 & 991 & 1160 & RI, GC-MS, Co \\
\hline 07 & Carene & 0.32 & - & 1001 & 1189 & RI, GC-MS \\
\hline 08 & Limonene & 1.27 & 1.13 & 1028 & 1193 & RI, GC-MS, Co \\
\hline 09 & 1,8-Cineole & 43.30 & 1.16 & 1033 & 1200 & RI, GC-MS, Co \\
\hline 10 & Linalool & 0.72 & 0.58 & 1095 & 1562 & RI, GC-MS, Co \\
\hline 11 & Undecane & 0.71 & 0.66 & 1100 & 1530 & RI, GC-MS, Co \\
\hline 12 & cis- $\beta$-Dihydroterpineol & - & 1.08 & 1138 & - & RI, GC-MS \\
\hline 13 & Isoborneol & - & 6.55 & 1156 & 1492 & RI, GC-MS, Co \\
\hline 14 & Pinocampheol & - & 3.15 & 1167 & 1519 & RI, GC-MS \\
\hline 15 & Terpinen-4-ol & 1.83 & 3.03 & 1177 & 1602 & RI, GC-MS, Co \\
\hline 16 & Isomentol & - & 0.53 & 1178 & - & RI, GC-MS, Co \\
\hline 17 & cis-Dihydrocarvone & - & 0.25 & 1194 & - & RI, GC-MS, Co \\
\hline 18 & trans-Dihydrocarvone & - & 0.36 & 1198 & - & RI, GC-MS, Co \\
\hline 19 & Carvacrol ethyl ether & - & 1.03 & 1294 & - & RI, GC-MS \\
\hline 20 & Carvacrol & - & 5.25 & 1297 & 1572 & RI, GC-MS, Co \\
\hline 21 & $\beta$-Bourbonene & 0.22 & - & 1384 & - & RI, GC-MS, Co \\
\hline 22 & Vanillin & 0.25 & - & 1392 & - & RI, GC-MS, Co \\
\hline 23 & cis-threo-Davanafuran & 1.28 & 1.77 & 1414 & 1569 & RI, GC-MS, Co \\
\hline 24 & ethyl-Vanillin & 0.40 & 0.27 & 1452 & - & RI, GC-MS \\
\hline 25 & $\beta$-Farnesene (E) & - & 0.34 & 1457 & - & RI, GC-MS, Co \\
\hline 26 & $\gamma$-Muurolene & 2.95 & 0.83 & 1477 & 1639 & RI, GC-MS, Co \\
\hline 27 & $\gamma$-Curcumene & - & 0.78 & 1480 & - & RI, GC-MS \\
\hline 28 & Cubenol & 3.07 & 6.90 & 1492 & 1633 & RI, GC-MS \\
\hline 29 & $\alpha$-Bisabolene $(\mathrm{Z})$ & 0.60 & - & 1504 & - & RI, GC-MS, Co \\
\hline 30 & cis-Calamenene & 0.44 & - & 1521 & - & RI, GC-MS \\
\hline 31 & Thymohydroquinone & 2.75 & - & 1552 & 1794 & RI, GC-MS \\
\hline 32 & Caryophyllene oxide & - & 3.30 & 1574 & 1987 & RI, GC-MS, Co \\
\hline 33 & Turmerol & 0.78 & - & 1577 & - & RI, GC-MS \\
\hline 34 & Spathulenol & 3.47 & - & 1579 & 2164 & RI, GC-MS, Co \\
\hline 35 & Globulol & 0.69 & - & 1582 & - & RI, GC-MS, Co \\
\hline 36 & Viridiflorol & - & 0.36 & 1591 & - & RI, GC-MS \\
\hline 37 & Guaiol & 4.91 & - & 1595 & 2077 & RI, GC-MS, Co \\
\hline 38 & Cedrol & - & 0.31 & 1597 & 2170 & RI, GC-MS, Co \\
\hline 39 & Isobornyl isobutyrate & - & 0.32 & 1602 & - & RI, GC-MS \\
\hline 40 & epi-Cedrol & - & 0.40 & 1608 & - & RI, GC-MS, Co \\
\hline 41 & $\alpha$-Acorenol & 0.44 & - & 1630 & 2207 & RI, GC-MS, Co \\
\hline 42 & 6-hydroxy-Isobornyl Isobutyrate & - & 0.58 & 1638 & - & RI, GC-MS \\
\hline 43 & $\beta$-Eudesmol & 0.32 & - & 1647 & 2240 & RI, GC-MS, Co \\
\hline 44 & Isoamyl geranate & - & 1.34 & 1650 & 1707 & RI, GC-MS \\
\hline 45 & $\beta$-Bisabolol & 2.02 & 2.62 & 1665 & 2189 & RI, GC-MS, Co \\
\hline 46 & epi- $\alpha$-Bisabolol & 0.33 & - & 1688 & 2235 & RI, GC-MS, Co \\
\hline 47 & $\beta$-Santalol (Z) & - & 12.88 & 1703 & 2004 & RI, GC-MS, Co \\
\hline \multirow[t]{2}{*}{48} & $\beta$-Santalol acetate $(\mathrm{Z})$ & - & 1.54 & 1823 & 2378 & RI, GC-MS \\
\hline & Total & 92.75 & 91.04 & & & \\
\hline
\end{tabular}

${ }^{\mathrm{a} C}$ Compounds listed in order of elution from a SE-54 column; ${ }^{\mathrm{b}} \mathrm{Kovats}$ Indices determined on apolar SE-54 column $\left(50-250{ }^{\circ} \mathrm{C} ; 4{ }^{\circ} \mathrm{C}\right.$ min $\left.{ }^{-1}\right)$; 'Kovats Indices determined on polar PEG-20M column $\left(50-250{ }^{\circ} \mathrm{C} ; 4{ }^{\circ} \mathrm{C} \mathrm{min}^{-1}\right)$; ${ }^{d}$ Identification: RI, Kovats index by Adams RP ${ }^{17}$, GC-MS, gas chromatography-mass spectroscopy; Co, co-injection of authentic material.

of sample B was richer in sesquiterpenoids than the oil of sample A, and was characterized by a high content of sabinene $(12.62 \%)$ and $\beta$-santalol (Z) (12.88\%), which are not present in sample A. The enantiomeric composition of the chiral monoterpene constituents were analyzed on a dual column system, ${ }^{10}$ using two $25 \mathrm{~m}$ fused silica columns coated with modified cyclodextrins (2,6-Me-3-Pe- $\beta$-CD and 6-Me-2,3-Pe- $\beta$-CD) as the chiral stationary phases. Of the chiral monoterpenes identified in the oils of A. sellowi, the main constituents were: (-)- 
sabinene, (+)- $\beta$-pinene, (+)- $\alpha$-pinene, and (+)-terpinen4-ol (see Table 2).

The essential oils were screened for biological activity using the brine shrimps lethality test. ${ }^{11}$ Samples $\mathrm{A}$ and $\mathrm{B}$ displayed high toxicity $\left(\mathrm{LC} 50=2.85 \mu \mathrm{g} \mathrm{mL}^{-1}\right)$ in the brine shrimp bioassay. Antimicrobial activity of samples A and B was determined by the broth micro dilution method, ${ }^{12,13}$ to determine the minimum inhibitory concentration (MIC) and the minimum lethal concentration (MLC). Table 3 shows that sample B exhibited a more potent antifungal activity against $S$. cerevisiae than sample A, probably due to the presence of carvacrol in sample B $(>5 \%) \cdot{ }^{14}$ Yet for antibacterial activity, our results indicate that $S$. epidermidis (MIC $=1.7 \mathrm{mg} \mathrm{mL}^{-1}$, samples A and B) was found to be the most sensitive while $S$. aureus, M. luteus, K. pneumoniae, E. coli and S. setubal were the most resistant bacteria $\left(\mathrm{MIC}=6.7-20 \mathrm{mg} \mathrm{mL}^{-1}\right)$. A chemical-composition and antibacterial activity comparison in our results (Table 3 ) demonstrates that the compounds present in greatest proportions as 1,8-cineole

Table 2. Enantiomeric distribuitions (\%) of monoterpenes in the $A$. sellowii essential oils determined by co-injection with authentic material

\begin{tabular}{lcccccc}
\hline \multirow{2}{*}{ Compound } & \multicolumn{2}{c}{ Sample A $(e e)$} & \multicolumn{2}{c}{ Sample B $(e e)$} & \multicolumn{2}{c}{ Kovats Indices } \\
\cline { 2 - 7 } & $(+) \%^{\mathrm{a}}$ & $(-) \%^{\mathrm{a}}$ & $(+) \%^{\mathrm{a}}$ & $(-) \%^{\mathrm{a}}$ & $(+)$ & $(-)$ \\
\hline Thujene & 100 & - & 100 & - & $920^{\mathrm{c}}$ & - \\
$\alpha$-Pinene & 98 & 02 & 98 & 02 & 969 & $964^{\mathrm{b}}$ \\
$\beta$-Pinene & 92 & 08 & 89 & 11 & 980 & $973^{\mathrm{c}}$ \\
Sabinene & - & - & - & 100 & - & $985^{\mathrm{c}}$ \\
Limonene & 89 & 11 & 93 & 07 & 1067 & $1061^{\mathrm{c}}$ \\
Linalool & 67 & 33 & 89 & 11 & 1255 & $1250^{\mathrm{b}}$ \\
Terpinen-4-ol & 78 & 22 & 92 & 08 & 1321 & $1330^{\mathrm{c}}$
\end{tabular}

a Percentage of enantiomeric excess of the chiral monoterpenes analyzed on a dual column system with chiral stationary phase $(2,6-$ Me-3-Pe- $\beta$-CD and 6-Me-2,3-Pe- $\beta$-CD); Kovats Indices determined on: ${ }^{\mathrm{b}} 6-\mathrm{Me}-2,3-\mathrm{Pe}-\beta-\mathrm{CD}$ and ${ }^{\mathrm{c}} 2,6-\mathrm{Me}-3-\mathrm{Pe}-\beta-\mathrm{CD}$.

Table 3. Antibacterial activity of the oils of A. sellowii (minimal inhibitory concentration (MIC) and the minimal letal concentration (MLC) in $\mathrm{mg} \mathrm{mL}^{-1}$ )

\begin{tabular}{lcccccc}
\hline Organisms $^{\mathrm{a}}$ & \multicolumn{2}{c}{ Sample A $^{\mathrm{b}}$} & \multicolumn{2}{c}{ Sample $\mathrm{B}^{\mathrm{b}}$} & Chloramph. $^{\mathrm{b}}$ & Nistatine $^{\mathrm{b}}$ \\
\cline { 2 - 7 } & MIC & MLC & MIC & MLC & MIC & MIC \\
\hline S. aureus & 6.7 & 16.0 & 16.0 & 16.0 & $2.50 \times 10^{-2}$ & - \\
S. epidermidis & 1.7 & 1.7 & 1.7 & 3.4 & $6.25 \times 10^{-3}$ & - \\
M. luteus & 16.0 & 16.0 & 6.7 & 6.7 & $6.25 \times 10^{-3}$ & - \\
K. pneumoniae & 6.7 & 6.7 & 6.7 & $>20.0$ & $1.25 \times 10^{-2}$ & - \\
E. coli & 8.0 & $>20.0$ & 6.7 & 16.0 & $1.25 \times 10^{-2}$ & - \\
S. setubal & 6.7 & 16.0 & 16.0 & 16.0 & $1.25 \times 10^{-3}$ & - \\
C.albicans & 16.0 & $>20.0$ & 16.0 & 16.0 & - & $8.12 \times 10^{-3}$ \\
S. cerevisiae & 4.0 & 8.0 & 2.0 & 4.0 & - & $4.06 \times 10^{-3}$ \\
\hline
\end{tabular}

a ATCC (American Type Culture Collection); ${ }^{\mathrm{b}}$ Mean of 3 replicates in $\mathrm{mg} \mathrm{mL}^{-1}$.
(> $40 \%$ in sample A and only $1.16 \%$ in sample $\mathrm{B})^{15}$ are not necessarily responsible for the greatest share of total activity. Thus, the activity of the less abundant components as carvacrol, terpinen-4-ol, linalool, $\beta$ pinene, $\mathrm{R}(+)$-limonene, myrcene ${ }^{16}$ should be considered or at least the activity could be attributed to a synergistic effect among components. Although the MICs and the MLCs results varied between test organisms, in most cases the MIC and MLC are equivalent, indicating an antimicrobial action of the oils. To our knowledge, the antimicrobial activity of A. sellowii essential oils is reported here for the first time.

\section{Experimental}

\section{Plant material}

The leaves of about 6-10 individuals of a wild population of Aloysia sellowii (to give a representative sample) were collected in two localities of Rio Grande do Sul (Santa Maria and Livramento), in three successive years at flowering time (October- November 2001-2003, one collection/year). Specimens were identified by Prof. Gilberto Zanetti (Dept. of Biology, University of Santa Maria, RS, Brazil). Voucher specimens (HDFI 166-170) were deposited at the Herbarium of the University of Santa Maria, RS, Brazil.

\section{Essential oil isolation and chemical analysis}

Fresh plant leaves were subjected to hydro distillation for $4 \mathrm{~h}$ using a modified Clevenger-type apparatus, followed by exhaustive extraction of the distillate with diethyl ether. After removal of the solvent, the yield of the crude oils was $1.4 \%$ and $1.2 \%(\mathrm{~m} / \mathrm{v})$ for sample A and B, respectively. The physical properties for sample A and B were: $d 25: 0.92 ; \eta \mathrm{d} 25: 1.48,[\alpha]_{\mathrm{D}}^{25}:+9.54$ (in Hexane, $c=0.22$ ) and $d 25: 0.89 ; \eta \mathrm{d} 25: 1.50,[\alpha]_{\mathrm{D}}^{25}$ : -17.9 (in hexane, $c=0.18$ ), respectively. The essential oils were submitted to GC analysis in a Varian $3800 \mathrm{Gas}$ Chromatograph equipped with a capillary fused silica column ( $25 \mathrm{~m}$ x $0.25 \mathrm{~mm}$; film thickness $0.2 \mu \mathrm{m}$ ) coated with SE-54 (The GC conditions used were: carrier gas $\mathrm{H}_{2}$ $\left(1 \mathrm{~mL} \mathrm{~min}{ }^{-1}\right)$; injector split/splitless $220^{\circ} \mathrm{C}$; FID Detector $280{ }^{\circ} \mathrm{C}$; column temperature $50{ }^{\circ} \mathrm{C}$ to $250{ }^{\circ} \mathrm{C}$ at $4{ }^{\circ} \mathrm{C}$ $\min ^{-1}$. GC-MS analyses were performed on a HP 5973$6890 \mathrm{GC}-\mathrm{MSD}$ system operating in the EI mode at $70 \mathrm{eV}$, equipped with a HP-5 crosslinked capillary column (30 $\mathrm{m} \times 0.25 \mathrm{~mm}$; film thickness $0.2 \mu \mathrm{m}$ ). The temperature of the column and the injector were the same as those from GC. The identification of the components of the oils was 
based on comparison of the retention times and Kovats Indices $\left(\operatorname{Ir}_{\mathrm{i}}=100 . \mathrm{n}+100 . \Delta \mathrm{n} . \mathrm{tr}_{\mathrm{i}}-\operatorname{tr}_{\mathrm{n}} / \operatorname{tr}_{\mathrm{m}}-\operatorname{tr}_{\mathrm{n}}\right)^{17}$ on both columns and mass spectra with those of NBS/NIST Library ${ }^{18}$ and those described by Adams. ${ }^{19}$ The chiral monoterpene constituents of A. sellowii oils were identified by peak enrichment in enantioselective capillary GC with two fused capillary columns, $25 \mathrm{~m} \mathrm{x}$ $0.25 \mathrm{~mm}$, film thickness $0.2 \mu \mathrm{m}$, coated with heptakis-(6O-methyl-2,3-di-O-pentyl)- $\beta$-cyclodextrin and octakis(6-O-methyl-2,3-di-O-pentyl)- $\gamma$-cyclodextrin, each diluted with the polysiloxane OV-1701 (1:1), using a Varian 3800 , equipped with a flame ionization detector (FID), and hydrogen as the carrier gas. All runs were performed with a temperature program from $35^{\circ} \mathrm{C}$ for 15 min and $35{ }^{\circ} \mathrm{C}$ to $180{ }^{\circ} \mathrm{C}$ at $3{ }^{\circ} \mathrm{C} \min ^{-1}$.

\section{Toxicity assays}

The preliminary biological evaluation of the essential oils of A. sellowii was determined using the brine shrimp lethality test according to Meyer et al. ${ }^{11}$ with some modifications. ${ }^{9}$ The brine shrimp eggs were hatched in artificial sea water ( $3.8 \mathrm{~g}$ sea salt per liter of water) and, after hatching ( 2 days old), the shrimp larvae were used for experimental bioassay. The oil was dissolved in DMSO and them added to the saline solution containing 3\% of tween 20. Emulsification was assisted by ultrasound and the dilutions of this stock solution were made with saline solution containing tween 20. Then, shrimp larvae were placed in multiwelled culture plate and test solution was added to each well (in triplicate). Saline solution with $3 \%$ tween 20 and DMSO was used as a negative control (LC50>1000 $\mu \mathrm{g} \mathrm{mL}^{-1}$ ), while potassium dichromate (LC50 $=20 \mu \mathrm{g}$ $\mathrm{mL}^{-1}$ ) and cinchonine (LC50 $=100 \mu \mathrm{g} \mathrm{mL}^{-1}$ ) were used as standard positive controls. ${ }^{9}$ Survivors were counted after $24 \mathrm{~h}$ and the LC50 values were determined in $\mu \mathrm{g}$ $\mathrm{mL}^{-1}$, using the Finney probit analysis ${ }^{20}$ obtained values with $95 \%$ confidence intervals.

\section{Antibacterial assays}

The antibacterial activities of the oils of samples A and $\mathrm{B}$ were assayed using the broth micro dilution method. A collection of eight microorganisms were used, including three Gram-positive bacteria: Staphylococcus aureus, Staphylococcus epidermidis, Micrococcus luteus, three Gram-negative bacteria: Klebsiella pneumoniae, Escherichia coli and Salmonella setubal, and two yeasts: Saccharomyces cerevisiae and Candida albicans. Standard strains of microorganisms were obtained from American Type Culture Collection (ATCC), and standard antibiotics chloramphenicol and nistatine were used in order to control the sensitivity of the microbial test. ${ }^{21}$ The minimal inhibitory concentration (MIC) was determined on 96 well culture plates by a micro dilution method using a microorganism suspension at a density of 105 CFU mL ${ }^{-1}$ with Casein Soy Broth incubated for 24 hours at $37{ }^{\circ} \mathrm{C}$ for bacteria, and Sabouraud Broth incubated for 72 hours at $25{ }^{\circ} \mathrm{C}$ for yeasts. The cultures that did not present growth were used to inoculate plates of solid medium (Muller Hinton Agar and Sabouraud Agar) in order to determine the minimal letal concentration (MLC). Proper blanks were assayed simultaneously and samples were tested in triplicate. Technical data have been described previously. ${ }^{12,13}$

\section{Acknowledgments}

This work was supported by FAPERGS (Fundação de Amparo à Pesquisa do Rio Grande do Sul) and CNPq (Conselho Nacional de Desenvolvimento Científico e Tecnológico).

\section{References}

1. Burkart, A.; Coleccion Científica del I.N.T.A. Flora Ilustrada de Entrerios (V), $1^{\text {st }}$ ed, Buenos Aires, Argentine, 1979.

2. Pascual, M.E.; Slowing, K.; Carretero, E.; Sánches, M.D.S.; Vollar, A.; J. Etnopharmacol. 2001, 76, 201.

3. Somavilla, N.; Dorow, T.S.C.; Ciência e Natura 1996, 18, 131.

4. Castro, O.; Fórum Pela Vida-Projeto Plantas Vivas, Assembléia Legislativa do RS: Porto Alegre, Brazil, 2001.

5. Soler, E.; Dellacassa, E.; Moyna, P.; Phytochemistry 1986, 25, 1343.

6. Carnat, A; Carnat, A.P.; Fraisse, D.; Lamaison, J.L.; Fitoterapia 1999, 70, 44.

7. Flach, A.; Simionatto, E.; Silva, U.F.; Zanatta, N.; Morel, A.F.; Linares, C.E.; Planta Med. 2002, 68, 836.

8. Gonzaga, W.A.; Weber, A. D.; Giacomelli, S.R.; Simionatto, E.; Dessoy, E.C.M.; Morel, A.F.; Planta Med. 2003, 69, 773.

9. Colegate, S.M.; Molyneux, R.J.; Bioactive Natural Products: Detection, Isolation and Structural Determination, CRC Press: EUA, 1993.

10. Konig, W.A.; Icheln, D.; Runge, T.; J. High Resolut. Chromatogr. 1992, 15, 184.

11. Meyer, B.N.; Ferrigni, N.R.; Putnam, J.E.; Jacobsen, L.B.; Nichols, D.E.; Planta Med. 1982, 45, 31.

12. Hammer, K.A.; Carson, C.F.; Riley, T.V.; J. Appl. Microbiol. 1999, 86, 985. 
13. National Committee for Clinical Laboratory Standards: Reference Method of Broth Dilution Antifungal Susceptibility Testing of Yeasts. Standard M77-T, NCCLS: Villanova,1995.

14. Pina-Vaz, C.; Rodrigues, A.G.; Pinto, E.; Oliveira, S.C.;Tavares, C.; Salgueiro, L.; Cavaleiro, C.; Gonsalves, M.J.; Oliveira, J.M.; J. Eur. Acad. Dermatol. Venereol. 2004, 18, 73.

15. Tzakou, O.; Pitarokili, D.; Chimou, I.B.; Harvala, C.; Planta Med. 2001, 67, 81.

16. Dorman, H.J.D.; Deans, S.G.; J. Appl. Microbiol. 2000, 88, 308.

17. Kovats, E. in Advances in Cromatography; Giddings, J. C.; Keller, R. A., eds.; Dekker, M. Inc.: New York, NY, 1965, vol I.
18. Massada, Y.; Analysis of Essential Oil by Gas Chromatography and Spectrometry, John Wiley \& Sons: New York, 1976.

19. Adams, R. P.; Identification of Essential Oil Components by Gas Chromatography/Mass Spectroscopy, Allured Publishing: Illinois- USA, 1995.

20. Finney, D.J.; Probit Analysis, $3^{\text {rd }}$ ed., Cambridge University Press: Cambridge, 1971.

21. FDA: Code of Federal Regulation 1991, 21, 300.

Received: August 13, 2004

Published on the web: October 11, 2005 